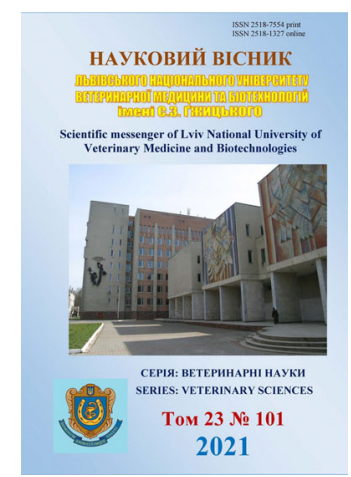

\author{
Науковий вісник Дьвівського націонадьного університету \\ ветеринарної медицини та біотехнодогій імені С.3. Гжицького. \\ Серія: Ветеринарні науки \\ Scientific Messenger of Lviv National University \\ of Veterinary Medicine and Biotechnologies. \\ Series: Veterinary sciences
}

\title{
Sexual cycle of cats and non-invasive diagnostic methods
}

\author{
O. V. Burlakova, V. Y. Stefanyk
}

Stepan Gzhytskyi National University of Veterinary Medicine and Biotechnologies Lviv, Ukraine

Article info

Received 01.02.2021

Received in revised form 04.03 .2021

Accepted 05.03.2021

Stepan Gzhytskyi National University of Veterinary Medicine and Biotechnologies Lviv, Pekarskaya Str., 50, Lviv, 79010, Ukraine.

Tel.: +38-096-905-47-66 E-mail: zooprofi@ukr.net
Burlakova, O. V., \& Stefanyk, V. Y. (2021). Sexual cycle of cats and non-invasive diagnostic methods. Scientific Messenger of Lviv National University of Veterinary Medicine and Biotechnologies. Series: Veterinary sciences, 23(101), 124-132. doi: 10.32718/nvlvet10120

Mostly all feral cats are listed in the IUCN International Red Book. This fact is caused by the negative impact of civilization on the ecosystem, including fauna. This trend applies equally to feral cats from the family Felidae (tigers, jaguars, leopards, snow leopards) and the family Felinae (caracal, serval, ocelot, etc.). The low population size of domestic species, namely lynx and forest cat in Ukraine, is alarming. The use of innovative biotechnological techniques in reproduction can have a positive effect on the conservation of endangered carnivorous species. These auxiliary methods are aimed at improving the technique of obtaining and cryopreservation of sperm, oocytes, in vitro fertilization, artificial insemination, embryo transplantation, as well as synchronization and regulation of the sexual cycle. This last element is key in ex situ conservation programs in zoos. Under physiological course, feline reproductive cycle is unique, as the physiology of the body as a whole. The wild cat family is the pinnacle of predator evolution. Today there are 39 species of this family in the world, including the domestic cat. Most feral cats are endangered. The main reasons for the decline in wild cat populations in the wild are habitat loss, fragmentation, human-animal conflict, and for some species, poaching for fur and medicine. Therefore, many scientists in the world face the issue of increasing reproductive capacity, improving methods of monitoring reproductive function and endocrine status, as different species of cats have significant differences in the sexual cycle. The main purpose of the work is to improve the reproductive properties in the reproduction of wild cats using noninvasive diagnostic methods. Reproduction is a key success factor, so understanding the basics of the reproduction function will help develop strategies to conserve and influence populations of different feline species.

Key words: wild feline, cat, feline reproduction, sexual cycle of cats, non-invasive diagnostic methods, sex hormones.

\section{Статевий цикл котячих та неінвазивні методи діагностики}

\author{
О. В. Бурлакова, В. Ю. Стефаник
}

Львівський національний університет ветеринарної медицини та біотехнологій імені С. 3. Гжсицккого, м. Львів, Украӥна

\footnotetext{
Практично усі дикі котячі знаходяться в міжнародній червоній книзі IUCN. Цей факт спричинений негативним впливом ичивілізації на екосистему, в тому числі на фауну. Ця тенденція однаково стосується як диких котів з родини Fеlidaе (тигрів, ягуарів, леопардів, сніжних барсів), так і родини Fеlinaе (каракала, сервала, очелота, і т.д.). Викликає тривогу низька чисельність популяиії вітчизняних видів, а саме рисі та лісового кота в Украӥні. Застосування інновачійних біотехнологічних методик у відтворенні можуть дати позитивний результат у збереженні зникаючих видів м ясоїдних. Ці допоміжні методи спрямовані на вдосконалення техніки отримання і кріоконсервачї сперми, ооцитів, запліднення іп vitro, штучного осіменіння, трансплантації ембріонів, а також синхронізаиії та регуляиії статевого ииклу. Цей останній елемент є ключовим в програмах охорони ех sіtи в зоопарках. За фізіологічним перебігом репродуктивний цикл котячих є унікальним, як і фізіологія організму в цілому. Сімейство диких котячих $\epsilon$ верииною еволючї хижаків. На сьогоднішній день в світі налічується 39 видів представників иього сімейства, в тому числі $і$ домашня кішка. Більшість диких кішок знаходяться під загрозою зникнення. Основні причини скорочення популяції диких кішок в природі - це втрата середовища існування, фрагментація, конфлікт між людьми і тваринами, а для деяких видів, браконьєрство
} 
заради хутра та ліків. Тому перед багатьма вченими в світі стоїть питання підвищення репродуктивної здатності, удосконалення методик моніторингу репродуктивної функиії та ендокринного статусу, так як різні види кошачих мають суттєві відмінності в перебігу статевого циклу. Основна мета роботи - покращити репродуктивні властивості при відтворенні диких котячих використовуючи неінвазивні методи діагностики. Розмноження є основним фактором успіху, тому розуміння основ функиії відтворення допоможе розробити стратегї для збереження і впливу на популяції різних видів котячих.

Ключові слова: дикі котячі, кішка, репродукція котячих, статевий цикл кішок, неінвазивні методи діагностики, статеві гормони..

\section{Вступ}

За фізіологічним перебігом репродуктивний цикл котячих є унікальним, як і фізіологія організму в цілому. Сімейство диких котячих $є$ вершиною еволюції хижаків. На сьогоднішній день в світі налічується 39 видів представників цього сімейства, в тому числі і домашня кішка (Nowell \& Jackson, 1996). Більшість диких кішок знаходяться під загрозою зникнення. Основні причини скорочення популяції диких кішок в природі - це втрата середовища існування, фрагментація, конфлікт між людьми і тваринами, а для деяких видів, браконьєрство заради хутра та ліків (Wilting et al., 2007). Тому перед багатьма вченими в світі стоїть питання підвищення репродуктивної здатності, удосконалення методик моніторингу репродуктивної функції та ендокринного статусу, так як різні види кошачих мають суттєві відмінності в перебігу статевого циклу (Trigo et al., 2013).

Основна мета роботи - покращити репродуктивні властивості при відтворенні диких кішок використовуючи неінвазивні методи діагностики. Розмноження $\epsilon$ основним фактором успіху, тому розуміння основ репродукції допоможе розробити стратегії для збереження і впливу на популяції різних видів котячих.

За основу фізіологічного перебігу статевого циклу кошачих прийнято використовувати домашню кішку, так як вона давно слугує моделлю для вивчення фізіології та репродукції диких кошачих (Howard et al., 1992). Домашні кішки відносяться до поліестральних тварин, феномен овуляції у яких полягає у іiі індукції під час статевого акту. Вони можуть досягати фізіологічної багатоплідної вагітності впродовж усього року, що дає їм змогу бути найплодовитішими з усіх видів домашніх тварин (Howard et al., 1996).

Кішки як і інші тварини набувають здатності до розмноження тільки при досягненні статевої зрілості. Вона починається 3 настанням першого статевого циклу у самки або виділення сперми у самця. Здатність до відтворення настає поступово. Поряд із загальним ростом і розвитком тварини швидко, але рівномірно росте і дозріває гіпофіз, гормональний вплив якого на яєчники викликає їх збільшення і провокує ріст та розвиток фолікулів у них. Фолікули, які дозрівають, виробляють статеві гормони (естрогени), котрі забезпечують ріст і розвиток матки й інших ділянок статевих шляхів Ці зміни приводять статевий апарат самки в стан функціональної готовності, зовнішнім проявом якої є перша тічка і статева охота, а внутрішнім - овуляція фолікула в яєчнику. Статева зрілість у домашніх кішок настає у 4-12-місячному віці. На проявлення цієї зрілості можуть впливати багато факторів, а саме: порода кішок (відомий той факт, що короткошерстні кішки досягають статевої зрілості раніше ніж довгошерсті), час народження (кошенята народженні у літню пору та восени досягають статевої зрілості в першу весну, у віці 5-6 міс., а кошенята народжені навесні досягають статевої зрілості тільки наступної весни в 12 міс). Терміни появи першого еструсу також залежать від стану організму, соціального середовища і особливостей їх харчування. Цікавим $€$ той факт, що кішки на вільному вигулі досягають статевої зрілості раніше, ніж кішки, які проживають в квартирах без вільного вигулу.

Статева зрілість проявляється завжди раніше ніж закінчується основний ріст і розвиток тварини. Використання тварин для відтворення зразу ж після настання статевої зрілості негативно позначається не тільки на самих тваринах, але й на їх нащадках. У них недостатньо розвинена статева i імунна системи, таз і молочна залоза. Фізіологічна зрілість характеризується завершенням формування організму і досягненням твариною 70 \% живої маси, властивої дорослим тваринам даної породи і статі. Тільки фізіологічно зрілих тварин можна використовувати для відтворення. Кішки досягають фізіологічної зрілості у віці 10-12 міс. Максимальна репродуктивна здатність досягається у віці від 2-8 років. Зниження репродуктивної функції натупає до 10-річного віку (England \& von Heimendahl, 2010).

При досягненні статевої зрілості статевий апарат самки підпорядковується певному функціональному ритму, в основі якого лежать процеси дозрівання фолікулів, овуляції домінантних фолікулів 3 наступним розвитком жовтих тіл в яєчниках синхронно зі змінами слизової оболонки матки. Всі ці процеси проходять взаємопов'язано, мають циклічний характер i спрямовані на створення сприятливих умов для транспорту статевих клітин у статевих органах самки, запліднення і розвиток вагітності.

Статевий (оваріальний) цикл (рос. половой цикл, англ. theseksualcycl, фp. cyciovarienne) - сукупність фізіологічних та морфологічних процесів в організмі статевозрілої самки, пов'язаних з розмноженням, які знаходяться під контролем нейрогуморальних механізмів регуляції і регулярно повторюються у сталому порядку протягом певного генетично закодованого проміжку часу.

Статевий цикл у кішок називають естральним(від гpeu. oestros- пристрасний потяг) притаманний для всіх ссавців за винятком людини. Він супроводжується еструсною поведінкою, за якою настає овуляція вихід яйцеклітини з фолікула.

В залежності від типу овуляції кішок відносять до рефлекторно овулюючих тварин. Овуляція настає тільки після спарування, яке призводить до викиду 
гіпоталамічного нейрогормона Гн-РГ, котрий діє на гіпофіз і викликає виділення ЛГ, а ЛГ діє на яєчник і викликає овуляцію.

Англійський вчений Уолтер Хіп що у 1898 р. описав 4 стадії статевого циклу: Передтічкова (proestrum), Тічка (oestrum, oestrus), Післятічкова (metoestrum, interoestrus), Зрівноваження (dioestrum s. anoestrum). Характеристика статевого циклу за У. Хіпом використовується і зараз у всьому світі.

Проеструс і еструс проявляються внаслідок розвитку фолікулів та збільшенням рівня ФСГ та ЛГ. У окремих самок статева активність не проявляється в період проеструсу, а у інших є прояви статевого збудження які характерні для періоду еструсу, але кішки не проявляють позитивної реакції на кота. Під час еструсу при ретельному огляді тварину ми можемо спостерігати певні клінічні ознаки прояву цієї стадії, які характеризуються незначною припухлістю вульви. Також еструс характеризується підвищеним статевим збудженням, посиленою вокалізацією, проявом характерної пози (спинний лордоз), проявляються підвищені грумінговізвички, знижується апетит. Іноді при еструсі також спостерігається маркування сечею території. Деякі особини не проявляють ніяких змін поведінки при еструсі, поводять себе агресивно, або пасивно до партнера, навіть при підвищеному рівні статевих гормонів, це може бути пов'язано з ієрархією в зграї, недосвідченістю, неуважністю, стресом, що призводить до “тихої тічки” (Djul'ger, 2004).

Протягом всієї фази еструсу фолікули, які розвиваються, підтримують концентрацію естрогенів на високому рівні. Через 3-6 діб від початку еструсу та у випадку відсутності овуляції, фолікули піддаються атрезії та відповідно рівень естрогенів знижується, статева поведінка змінюється і кішка повертається в стадію інтереструсу.

Овуляція. Особливістю феномену овуляції у кішки є індукована овуляція.Для цього потрібна механічна стимуляція вульви та стінки піхви, що викликає активацію нейронів в гіпоталамусі та вивільнення ГнРГ, який у свою чергу викликає продукцію передньою долею гіпофіза ЛГ. Цей процес відбувається завдяки статевому акту, але овуляцію можна також викликати штучно, стимулюванням вульви ватним тампоном. Викид ЛГ відбувається через декілька хвилин після спарювання та найвищий його рівень досягає свого піку через 2-4 години. У деяких кішок овуляція може бути без статевого акту - “спонтанна овуляція”, стимуляція рецепторів відбувається при надмірному вилизуванні вульви при грумінгу, частіше зустрічається у вікових кішок в присутності кота (Shille et al., 1983).

Лютеальна фаза. Овуляція відбуваєтьсячерез 24 48 годин після спалаху ЛГ, відповідно концентрація естрогенів значно знижується. Тривалість фази еструсу у кішок, які овулювали, коротша від тих, у яких овуляція не відбулася. Процес запліднення відбувається в яйцепроводах, потім ембріони мігрують через 3-4 доби після овуляції в порожнину матки. ЛГ не тільки викликає овуляцію, але й стимулює розвиток i функціонування жовтих тіл, які продукують прогестерон. На початковому етапі лютеальної фази профіль прогестерону у сироватці крові вагітних і невагітнихкішок які овулювали не відрізняється. Встановлена різниця у тривалості продукції прогестерону а, саме у вагітних кішок цей період довший, ніж у невагітних.

Лютеальна фаза статевого циклу у невагітних кішок складає приблизно половину терміну вагітності, i за нею не слідує обов'язковий анеструс. Це дає змогу швидко повернутися до циклічної активності і збільшити шанси на успішне спарювання в період розмноження (Johnson \& Gay, 1981).

Період вагітності. Рівень прогестерону в плазмі крові через 24 год після спалаху ЛГ та овуляції, швидко збільшується. Далі концентрація прогестерону починає зростати і досягає свого піку на 25-ту добу від моменту овуляції (рис. 1). Відбувається невелике зниження концентрації прогестерону та його рівень залишається сталим приблизно до 60-ї доби від моменту овуляції (England \& von Heimendahl, 2010).

Окрім того через 24 год після овуляції починає збільшуватися рівень пролактину та на 50-ту добу досягає сталого рівня, за декілька діб до родів знову його рівень зростає (Banks et al., 1983).

Ще одним так званим гормоном вагітності є релаксин, який продукує плацента. Концентрація релаксину починає поступово збільшуватися 3 моменту імплантації ембріонів та поступово зростає досягаючи максимуму на 50 добу після овуляції. Релаксин можевпливати на жовте тіло, опосередковано стимулює секрецію пролактину у гіпофізі або може стимулювати інші невідомі лютеотропні фактори. Цей гормон відповідає за розрихлення сполучної тканини тазу для полегшення родового процесу (Stewart \& Stabenfeldt, 1985).

Визначення рівня релаксину та пролактину можуть застосовуватися, як діагностичні тести при діагностиці з 30-ї доби вагітності, тому що у невагітних кішок підвищення їх концентрації не виявлено.

Рівень естрогенів знижується після овуляції та залишається на базальному рівні протягом вагітності. 3 60-ї доби його концентрація зростає та перед родами знижується. До $10 \%$ кішок можуть демонструвати так званий поведінковий еструс протягом 20-40-ї доби вагітності.

Кішкам притаманний феномен суперфекундації. Цей феномен характеризується такою особливістю коли декілька самців можуть спарюватися 3 однією кішкою та спермії різних самців запліднюють яйцеклітини під час однієї овуляції - це у свою чергу призводить до народження в одному приплоді кошенят від різних самців.

Незадовго до родів рівень прогестерону стрімко знижується. Це пов'язано з секрецією кортизола у плода. Цей процес характеризується зниженням температури тіла у кішки до $36,5^{\circ} \mathrm{C}$ та є одним 3 передвісників родів (England \& von Heimendahl, 2010). 


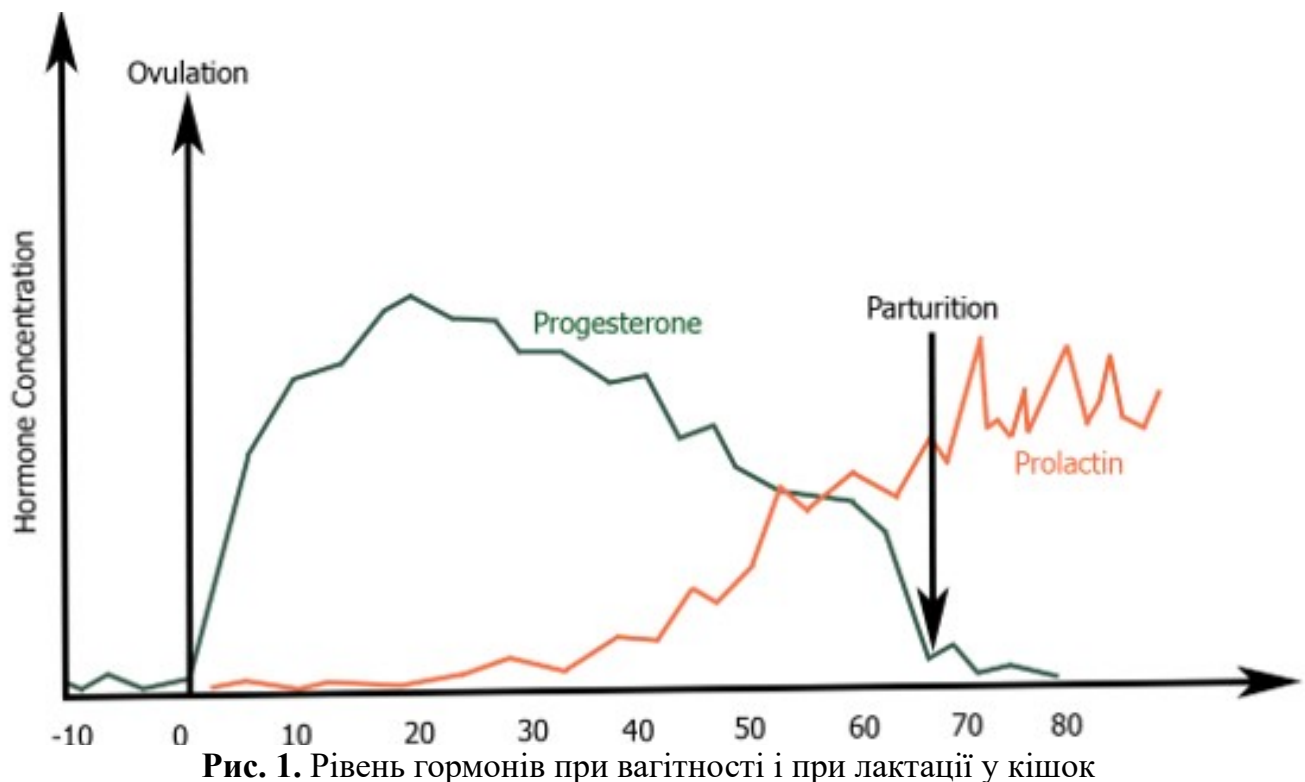

(Gary England and Angelika von Heimendahl 2010)

Псевдовагітність. У кішок, які овулювали і не відбулося процесу запліднення, профілі рівня прогестерону на початкових етапах після еструсу не відрізняються від вагітних, так само рівень прогестерону збільшується і досягає свого максимуму на 25-ту добу від моменту овуляції. Далі рівень прогестерону знижується і досягає базальних значень на 30-40 добу (рис. 2). Вважається, що таке поступове зниження прогестерону відбувається за рахунок відсутності специфічного для вагітності лютеотрофного фактору.

Концентрація пролактину не збільшується так само, як і рівень релаксину. Ззовні псевдовагітність не проявляється, крім збільшення сосків у деяких особин. Поведінка також не змінюється. Фактично, єдиним клінічним проявом є відсутність циклічної активності, в порівнянні з кішками у яких була відсутня овуляція (Banks et al., 1983).

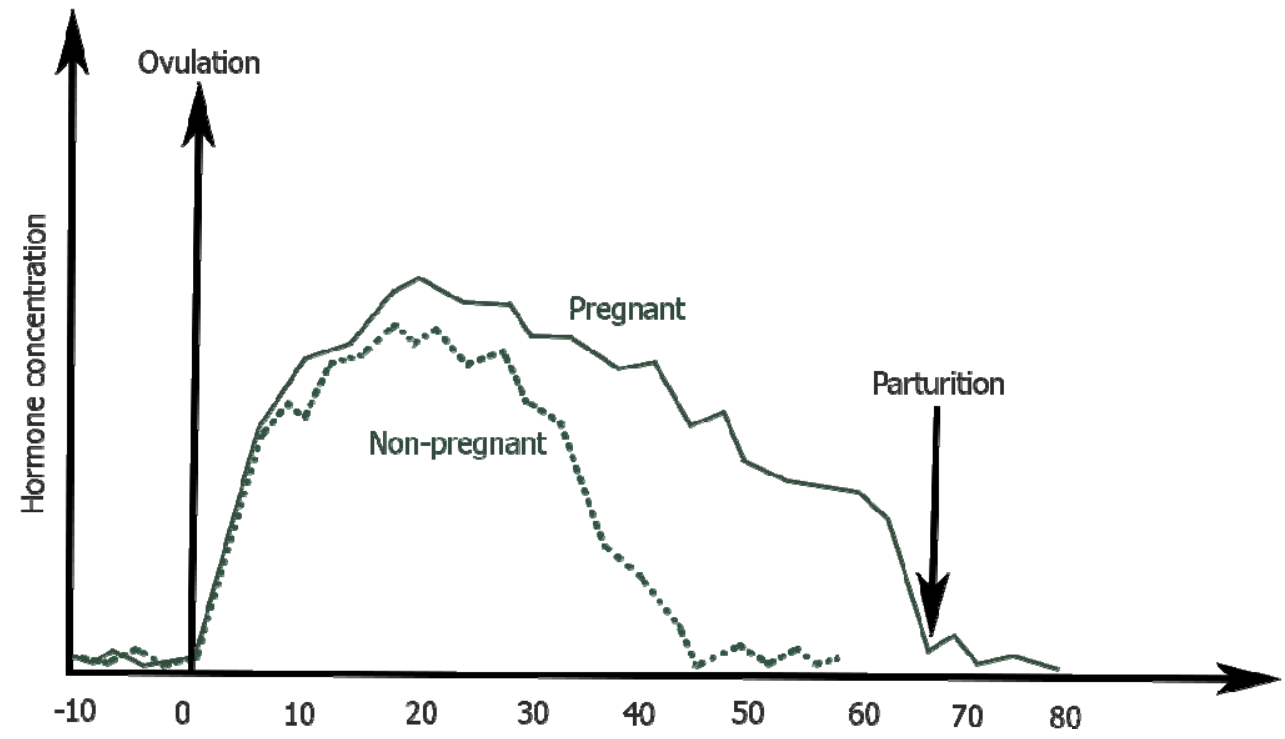

Рис. 2. Рівень прогестерону в лютеальну фазу при вагітності та псевдовагітності (Gar England and Angelika von Heimendahl 2010)

Інтереструс (метаеструс) - це період, між одним еструсом та наступним у випадку якщо овуляція не відбулася. Впродовж цього часу концентрація естрогенів низька і прояви сексуальної поведінки відсутні. Тривалість інтереструсу різна, але найчастіше 8-21-а доба. В кінці інтереструсу збільшується секреція ЛГ і ФСГ, що призводить до проявлення еструсу і статевої активності (Wildt et al., 1998).
Анеструс - це відсутність циклічної активності яєчників, яка проявляється в період короткого світового дня. Як уже зазначалося це пов'язано з секрецією мелатоніну. Під час анеструсу кішки не підпускають кота, проявляють агресію і уникають спілкування. Стадія анеструсу триває протягом 3-4 міс. Зимового періоду, коли тривалість світової доби є коротша. Доведено, що секреція мелатоніну з шишкоподібної 
залози відіграє важливу роль в регуляції статевого циклу. Цікаво, що концентрація як мелатоніну, так і пролактину збільшені в період коротшого світового дня та нижчий їх рівень в період інтенсивного освітлення. В племінних популяціях 3 контрольованим режимом освітлення кішки можуть проявляти статеву активність і в зимовий період (Wildt et al., 1998).

Статева циклічність це чергування стадій статевого циклу і є нормою для всіх здорових кішок, що досягли статевої зрілості. Циклічність продовжується протягом усього життя до настання клімактеричного періоду.

Котячі розповсюджені в усьому світі. Від місця їх існування залежать і особливості репродуктивної функції. Базуючись на літературних даних, усі види котячих можна поділити за перебігом статевого циклу на моно-, оліго-, та поліестральні (табл. 1) (Najdenko, 2015). Види 3 моноестральним статевим циклом, як правило, проявляють еструс один раз на рік, олігоестральним - декілька разів, але впродовж певного періоду року, поліестральним відповідно декілька разів впродовж усього року. У окремих літературних повідомленнях вказується, що у ряду видів диких котячих характер статевих цикліву одного й того ж виду може змінюватися в залежності від існування у різних частинах ареалу (Najdenko, 2015). Види котячих з поліестральним статевим циклом в основному розміщуються в тропічних та екваторіальних широтах. Центри ареалів місць існування $з$ олігоестральним розміщені в північніших i південніших широтах. У помірних широтах існують види з моноестральним циклом.

Так як різні види кошачих мають відмінності в перебігу статевого циклу виникла гостра необхідність в розробці методик для точної оцінки ендокринного статусу диких і зоопаркових тварин. Визначення репродуктивного статусу $\epsilon$ одним із важливіших факторів ефективного керування зусиллями по використанню допоміжних репродуктивних технологій. Методи (штучного осіменіння, екстракорпорального осіменіння і / або пересадка ембріонів) залежать від точних знань основ репродуктивної фізіології даного виду. Для проведення ефективного штучного осіменіння, важливим елементом є визначення оптимального часу. У випадку коли дана методика застосовується у диких кошачих необхідною умовою є визначення рівня статевих гомонів тому для цього використовують неінвазивні методи діагностики (Schwarzenberger et al., 1996).

\section{Таблиця 1}

Поділ видів диких котячих за проявленням статевого циклу (Najdenko, 2015)

\begin{tabular}{|c|c|c|}
\hline Тип статевих циклів & Види диких котячих & Літературні джерела \\
\hline Моноестральні & $\begin{array}{c}\text { Манул } \\
\text { Свразійська рись } \\
\text { Канадська рись } \\
\text { Сніжний барс } \\
\text { Піренейська рись } \\
\text { Китайська кішка } \\
\end{array}$ & $\begin{array}{c}\text { Swanson et al., } 1996 \\
\text { Найденко, 2005 } \\
\text { Fanson et al., } 2010 \\
\text { MacCarthy, Chapron, } 2003 \\
\text { Goritz et al., 2009 } \\
\text { Sanderson et al., 2010 } \\
\end{array}$ \\
\hline Олігоестральні & $\begin{array}{c}\text { Далекосхідний кіт } \\
\text { Червона рись } \\
\text { Чорнонога кішка } \\
\text { Барханна кішка } \\
\text { Європейський лісовий кіт } \\
\text { Пампасська кішка } \\
\text { Хаус } \\
\end{array}$ & $\begin{array}{c}\text { Павлова, 2010 } \\
\text { Stys, Leopold, } 1993 \\
\text { Molteno et al., } 1998 \\
\text { Гептнер, Слудський, } 1972 \\
\text { Гептнер, Слудський, } 1972 \\
\text { Silveira, } 1995 \\
\text { Гептнер, Слудський, } 1972 \\
\end{array}$ \\
\hline Поліестральні & $\begin{array}{c}\text { Тигр } \\
\text { Леопард } \\
\text { Лев } \\
\text { Гепард } \\
\text { Оцелот } \\
\text { Онцилла } \\
\text { Кіт-риболов } \\
\text { Домашня кішка } \\
\text { Ягуар } \\
\text { Димчастий леопард } \\
\text { Кішка Теммінка } \\
\text { Сервал } \\
\text { Каракал } \\
\text { Пума } \\
\text { Бенгальська кішка } \\
\text { Мармурова кішка } \\
\text { Ягуарунді }\end{array}$ & $\begin{array}{c}\text { Byers et al., 1990 } \\
\text { Cunningham, Gross, } 2000 \\
\text { Brown et al., } 1996 \\
\text { Graham et al., 1995 } \\
\text { Brown, 2006 } \\
\text { Morais et al., 2002 } \\
\text { Santymire et al., } 2011 \\
\text { Prescott, 1973 } \\
\text { Morato et al., 2004 } \\
\text { Yamada, Durant, 1989 } \\
\text { Mellen et al., 1989 } \\
\text { Sunquist, Sunquist, } 2002 \\
\text { Bernard, Stuart, 1987 } \\
\text { Eaton, Verlander, 1977 } \\
\text { Adachi et al., 2010 } \\
\text { Sunquist, Sunquist, 2002 } \\
\text { De Oliveira, 1998 }\end{array}$ \\
\hline
\end{tabular}

Визначення концентрації статевих гормонів у сировотці крові є найбільш точним відображенням активності гонад. Ця методика широко використовуєть- ся для моніторингу репродуктивної функції і ендокринного статусу у тварин. Процес відбору крові у диких тварин характеризується негативними наслід- 
ками - травматизацією і стресом (Putranto, 2011). У випадку діагностики вагітності іммобілізація може призвести до переривання вагітності, тобто $є$ ризики як для материнського організму, так і для плоду.

Радіоімунний аналіз (PIA). 380 -х років XX століття почали використовувати неінвазійні методи відбору матеріалу для характеристики ендокринної функції у різних видів тварин включаючи і котячих 3 використанням сечі та калу (Lasley \& Kirkpatrick, 1991; Schwarzenberger et al., 1996; Touma \& Palme, 2005). Аналіз гормонів в екскрементах проводили за допомогою PIA аналізу. Радіоімунний аналіз (скор. PIA; англ. Radioimmunoassay, RIA), також називається радіоімуннологічний або ізотопний імунологічний аналіз - це метод кількісного визначення біологічно активних речовин в біологічних рідинах, заснований на конкурентному зв'язуванні стабільних речовин і аналогічних їм мічених радіонуклідом речовин зі специфічними зв'язуючими системами, з подальшої детекцією на спеціальних лічильниках - радіоспектрометрах.

Вперше метод був розроблений Соломоном Берсон і Розалін Сасмен Ялоу в $1950-$ х роках. За допомогою цього методу вони вивчали кліренс інсуліну у хворих на діабет. Р. Ялоу отримала за це Нобелівську премію в 1977 році.

Для мітки антигенів чи антитіл в більшості випадків використовується ізотоп йоду 125I, який має період напіврозпаду 60 днів і високу питому радіоактивність.

Моніторинг рівня естрогенів та прогестерону у фекаліях за допомогою РІА став рутиною процедурою в повсякденному контролі репродуктивного статусу у зоопаркових тварин (Brown, 2006; Schwarzenberger \& Gogarten, 2007; Umapathy et al., 2013; Kumar et al., 2014) так як має свої переваги:

1. концентрація гормонів у плазмі крові протягом доби піддається коливанням і ситуативних варіацій концентрації, а концентрація метаболітів гормонів в екскрементах $\epsilon$ інтегрованим сталим показником за період часу, що згладжує подібні коливання і в значній мірі спрощує аналіз даних (Pavlova \& Najdenko, 2008);

2. проводиться з відсутністю стресу, травматизації та ризику для дослідника;

3. екскременти від тварин легко збирати без обмеження часу і періоду (Putranto et al., 2007; Putranto et al., 2007), а також піддавати заморозці для зберігання до проведення досліджень (Putranto, 2011).

Сеча та проби калу можуть бути зібрані для оцінки репродуктивного статусу у екзотичних тварин в неволі, але збір сечі характеризується труднощами у тварин, які знаходяться на вільному вигулі. Тому проби калу - найбільш практичний і інформативний метод відбору матеріалу для діагностики репродуктивного статусу диких котячих.

Визначення рівня статевих стероїдів в основному використовують для вивчення стану репродуктивної системи і надає інформацію про статевий цикл, вагітність, аборти, статеве дозрівання, репродуктивну поведінку, сезонність і моніторинг лікувальних заходів (Schwarzenberger et al., 1996).

Метаболізм гормонів. Корм перетравлюється i виводиться з організму через ШКТ у вигляді відходів. Кал містить багато важливих фізіологічних сигналів, таких як статеві гормони і їх метаболіти. В основному статеві гормони синтезуються 3 холестерину і переносяться током крові зв'язаними зі специфічними білками-носіями, такими як глобулін, пов'язуючий статеві гормони; або глобулін, пов'язуючий кортикостероїди. Ці гормони діють на органи-мішені і перетворюються на різноманітні метаболіти за допомогою 5аабо 5в- гідрогенази i 3a- або 3в-онстероіндегідрогенази, потім вони виводяться з сечею через нирки і з жовчю в кал (Putranto, 2011). 85-95 \% метаболітів стероїдних гормонів виводиться з фекаліями у домашньої кішки (Brown, 2006). Зокрема, метаболіти прогестерону (P4) у домашніх кішок метоболізуються і виводяться в основному як коньюговані і неконьюговані метаболіти з фекаліями (Brown et al., 1994). Повідомлялось, що у диких котячих, а саме у леопардової кішки(felisbengalensis) i димчатого леопарда, метаболізм Р4 може бути схожим і представляє собою майже один коньюгований метаболіт(більше $90 \%$ ). Однак у гепарда він був ідентифікований як три імунореактивні метаболіта, фракціонуючий у відсотковому співвідношенні 42:51:7 \% відповідно (Brown et al., 1994).

Введення радіоактивно міченого естрадіолу - 17 i прогестерону домашнім кішкам показало, що 95 \% метаболітів виводиться 3 калом в продовж 1-2 діб (Brown, 2006). Застосування високоефективних методик, а саме: рідинна хроматографія, газ хроматографія, мас-спектрометрія і аналізи імунореактивності виявили, що:

1. Фекальні естрогени складаються, в основному, $з$ неконьюгованих і коньюгованих (3-сульфат, 17сульфат, 17-сульфат) естрадіолів, 3 незначною кількістю естрона і естріола.

2. Прогестерон метаболізується і виводиться, в основному, у вигляді полярних з'єднань (більше $75 \%$ ), можливо коньюганти і деякі неконьюговані прегнани, які також можуть перехресно реагувати 3 антитілами при PIA (Brown et al., 1994).

Методика виділення метаболітів статевих гормонів 3 калових мас включає застосування кип'ятіння, перемішування і поєднання в комбінаціях з органічними розчинниками (етанол, метанол), які містять не менше 10 \% води або буферу для кращого відновлення коньюгованих стероїдів (Brown, 2011).

Був доведений біологічний взаємозв'язок між рівнем статевих гормонів в плазмі та екскрементах. Результати аналізу стероїдів показали, що значне збільшення концентрації естрогену у фекаліях були пов'язані з поведінковим еструсом (Brown, 2011).

Природне спарювання / або введення хоріон гонадотропіну людини також були ідентифіковані наступним збільшенням концентрації метаболітів прогестерону в калі, що вказує на овуляцію і лютеїнізацію. Усі зміни рівнів стероїдів в екскрементах чітко корелювали зі змінами рівня стероїдів в периферичному крово- 
обігу у котячих, які підлягали аналогічному лікуванню (Brown et al., 1994).

Таким чином визначення статевих гормонів у екскрементах $\epsilon$ важливою методикою для вивчення репродуктивної функції котячих, а саме дає:

1. Характеристику естрального циклу.

2. Визначення спонтанної та індукованої овуляції.

3. Вивчення впливу сезону, а також цілого ряду інших чинників на репродуктивну функцію.

За останній час були досягнуті великі успіхи в розробці неінвазивних методів моніторингу функції яєчників у різних видів тварин за допомогою імунологічного аналізу метаболітів стероїдів в сечі і калі (Lasley \& Kirkpatrick, 1991; Brown et al., 1994; Brown, 2006). Хоча радіоімунний аналіз (PIA) був переважаючим аналітичним методом, який використовували в минулому, його використання має багато недоліків (Brown, 2006). В РІА використовуються радіоактивні матеріали, використання яких потребує спеціальних ліцензій, спеціалізованого і дорогого обладнання для виявлення, а також небезпечні для здоров'я при використанні і утилізації реактивів (Lasley \& Kirkpatrick, 1991).

Імуноферментний аналіз (ІФА). Імуноферментний аналіз (IФA, англ. Enzymelinkedimmunosorbentassay, ELISA) - імунологічний метод якісного або кількісного лабораторного визначення різних макромолекул, низькомолекулярних 3'єднань, вірусів та ін. на основі специфічної реакції антиген-антитіло. Велика кількість достоїнств методу IФА сприяли його широкому застосуванню в наукових дослідженнях різних галузей медицини, мікробіологічної та харчової промисловості, сільського господарства, охороні навколишнього середовища. Позитивними факторами даного методу є: простота методів реєстрації, висока стабільність реагентів, можливість створення каскадних систем з посилення різних хімічних сигналів та відносно низька ціна в порівнянні 3 іншими методами.

Отже, імуноферментні аналізи (IФА) є кращими методами для проведення діагностики рівня стероїдів у фекаліях в зоопарках та в польових умовах, тому що вони виключають потребу в радіоактивних матеріалах і громісткому дорогому обладнанні. Як відомо прогестерон виводиться 3 екскрементами в більшості як неконьюговані метаболіти (прогестагену) і раніше в PIA використовувалися антитіла, які перехрестно реагували 3 різними прогестагенами. При ІФА на прогестерон у самок африканських слонів, чорного носорогу, білого носорогу, окапі і бегемотів використовували антитіла широкого спектру дії, які підходять для сиворотки крові і також для фекалій. Чіткі профілі прогестагена, отримані у цих видів, доводять, що описаний ІФА буде таким ж універсальним, як і PIA, i може бути практичною і економічною альтернативою PIA для моніторингу функції гонад у зоопаркових тварин (Graham et al., 2001).

Було проведене вивчення концентрації прогестагену в фекаліях у гепардів за допомогою ІФА. Профілі прогестагена в калі були аналогічні профілю прогестерона в сироватці. Концентрації прогестагена в калі i сировоточного прогестерону залишалися на базовому рівні до моменту статевого акту. В середньому профіль прогестагена в калі під час вагітності збільшився через 3-4 доби після спарювання і залишався високим до родів. При абортах рівень прогестагену відразу повертався до базового рівня. Щоб вивчити зміни компонентів метаболітів прогестагена при вагітності, фекальні прогестагени аналізували за рідинної хроматографії та ІФА. Дослідники дійшли висновків, що метод ІФА корисний для встановлення вагітності і моніторингу лютеїнової активності у вагітних гепардів (Adachi et al., 2011).

Інші дослідники вивчали репродуктивний статус самок амурських тигрів шляхом оцінки змін в калі під час природної активності яєчників і вагітності, а також визначали наявність прогестерона Р4 і типи метаболітів Р4, що виділяються організмом 3 калом. Вміст Р4 іестрадіолу 17в (Е2) вимірювали за допомогою ІФА, а метаболіти Р4 розділяли за допомогою рідинної хроматографії. Результати ІФА показали, що під час природної активності яєчників кількість Е2 вказала на циклічні зміни. Кількість Р4 у невагітних тигриць не підвищувалась, а при вагітності значно збільшувалась відразу після статевого акту в 2-3 рази. Всі ці дослідження підтверджують можливість використання ІФА методів для того, щоб оцінювати активність яєчників, такі як лютеїнова фаза або фолікулярна активність (овуляція), за допомогою ендокринного моніторингу на основі естрадіолу - 17B і прогестерону у фекаліях (Putranto, 2011).

Одна $з$ основних проблема при аналізі фекальних стероїдів виникає через інактивацію гормонів шлунково-кишковими бактеріями і екзогенними мікробами. Зразки фекалій необхідно зберігати не більше декількох годин після збору, а потім заморожувати, інактивуючи розвиток мікрофлори. Це $\epsilon$ основною рекомендацією при зборі екскрементів. Але, нажаль, у польових умовах і віддалених районах це не завжди можливо, тому існують методи консервування фекалій в спиртах(етанолі, метанолі). Доведено, що спирти стабілізують фекальні естрогени і прогестерон, вбиваючи розвиток мікрофлори і інактивують пов'язані 3 ними ферменти, зберігаючи проби фекалій з естрогеном і прогестероном впродовж 21 год при різних температурах навколишнього середовища. А потім потрібно обов'язково заморозити до $-20{ }^{\circ} \mathrm{C}$. Це дає можливість більш широкого і зручного використання неінвазивних методик у польових умовах (Beehner \& Whitten, 2004).

\section{Висновки}

Визначення рівня стероїдів у фекаліях за допомогою ІФА відкрило нові можливості для вивчення репродуктивного статусу диких кошачих, впливу лікувальних препаратів на репродуктивну систему, можливості детальної оцінки причин неплідності. ІФА метод простий і можливий для виконання в наших умовах. Так як 90 \% стероїдів у кішок виводиться 3 фекаліями, збір матеріалу спрощує аналіз, дозволяє проводити його без стресу для тварини, унеможлив- 
лює травматизацію і зменшує ризики для дослідника. Таким чином визначення рівня статевих гормонів у екскрементах $\epsilon$ важливою методикою для вивчення репродуктивної функції котячих, яка надасть змогу покращити функцію відтворення у них.

\section{References}

Adachi, I., Kusuda, S., Kawai, H., Ohazama, M., Taniguchi, A., Kondo, N., Yoshihara, M., Okuda, R., Ishikawa, T., Kanda, I., \& Doi, O. (2011). Fecal Progestagens to Detect and Monitor Pregnancy in Captive Female Cheetahs (Acinonyx jubatus). Journal of Reproduction and Development, 57(2), 262-266. doi: 10.1262/jrd.10-057T.

Banks, D. H., Paape, S. R., \& Stabenfeldt, G. H. (1983). Prolactin in the cat: I. Pseudopregnancy, pregnancy and lactation. Biol. Reprod., 28(4), 923-932. doi: 10.1095/biolreprod28.4.923.

Beehner, J. C., \& Whitten, P. L. (2004). Modifications of a field method for fecal steroid analysis in baboons. Physiology \& Behavior, 82(2-3), 269-277. doi: 10.1016/j.physbeh.2004.03.012.

Brown, J. L. (2006). Comparative endocrinology of domestic and nondomestic felids. Theriogenology, 66(1), 25-36. doi: 10.1016/j.theriogenology.2006.03.011.

Brown, J. L. (2011). Female reproductive cycles of wild female felids. Anim Reprod Sci., 124(3-4), 155-162. doi: 10.1016/j.anireprosci.2010.08.024.

Brown, J. L., Wasser, S. K., Wildt, D. E., \& Graham, L. H. (1994). Comparative aspects of steroid hormone metabolism and ovarian activity in felids, measured noninvasively in feces. Biol Reprod., 51(4), 776-786. doi: 10.1095/biolreprod51.4.776.

Djul'ger, G. P. (2004). Akusherstvo, ginekologija i biotehnika razmnozhenija koshek. Uchebnoe posobie. M.: Kolos (in Russian).

England, G., \& von Heimendahl, A. (2010). BSAVA Manual of Canine and feline reproduction and neonatology. Secondedition, 8-12.

Graham, L., Schwarzenberger, F., Möstl, E., Galama, W., \& Savage, A. (2001). A versatile enzyme immunoassay for the determination of progestogens in feces and serum. Zoobiology, 20(3), 227-236. doi: 10.1002/zoo.1022.

Howard, J. G., Barone, M. A., Donoghue, A. M., \& Wildt, D. E. (1992). The effect of preovulatory anaesthesia on ovulation in laparoscopically inseminated domestic cats. J. Reprod. Fertil., 96(1), 175-186. doi: 10.1530/jrf.0.0960175.

Howard, J. G., Byers, A. P., Brown, J. L., Schwartz, R. J., Evans, M. Z., \& Barrett, S. J. (1996). Successful ovulation induction and laparoscopic intrauterine artificial insemination in the clouded leopard (Neofelis nebulosa). Zoo Biol., 15, 55-69. doi: 10.1095/biolreprod56.4.1059.

Johnson, L. M., \& Gay, V. L. (1981). Luteinizing hormone in the cat. I. Tonic secretion. Endocrinology, 109(1), 240-246. doi: 10.1210/endo-109-1-240.

Kumar, V., Reddy, V. P., Kokkiligadda, A., Shivaji, S., \& Umapathy, G. (2014). Non-invasive assessment of reproductive status and stress in captive Asian elephants in three south Indian zoos. Gen Comp Endocrinol, 201, 37-44. doi: 10.1016/j.ygcen.2014.03.024.

Lasley, B. L., \& Kirkpatrick, J. F. (1991). Monitoring Ovarian Function in Captive and Free-Ranging Wildlife by Means of Urinary and Fecal Steroids. Journal of Zoo and Wildlife Medicine, 22(1), 23-31. URL: https://www.jstor.org/stable/20095115?seq=1.

Najdenko, S. V. (2015). Biologija razmnozhenija koshachih: Mehanizmy povyshenija reproduktivnogo uspeha. Dissertacija na soiskanie uchenoj stepeni doktora biologicheskih nauk. Moskva (in Russian).

Nowell, K., \& Jackson, P. (1996). Wild Cats. Status Survey and Conservation Action Plan. IUCN/SSC Cat Specialist Group. IUCN, Gland. URL: https://portals.iucn.org/ library/node/6998.

Pavlova, E. V., \& Najdenko, S. V. (2008). Neinvazivnyj monitoring gljukokortikoidov v ekskrementah dal'nevostochnogo lesnogo kota (Prionailurus bengalensis euptilurus). Zoologicheskijzhurnal, 87(11), 1375-1381 (in Russian).

Putranto, H. D. (2011). A non-invasive identification of hormone metabolites, gonadal event and reproductive status of captive female tigers. Biodiversitas Journal of Biological Diversity, 12(3). doi: 10.13057/biodiv/ d120302.

Putranto, H. D., Kusuda, S., Hashikawa, H., Kimura, K., Naito, H., \& Doi, O. (2007). Fecal Progestins and Estrogens for Endocrine Monitoring of Ovarian Cycle and Pregnancy in Sumatran Orangutan (Pongo abelii). Japanese Journal of Zoo and Wildlife Medicine, 12(2), 97-103. doi: 10.5686/jjzwm.12.97.

Putranto, H. D., Kusuda, S., Ito, T., Terada, M., \& Inagaki, K. (2007). Reproductive Cyclicity Based on Fecal Steroid Hormones and Behaviors in Sumatran Tigers, Panthera tigris sumatrae. Japanese Journal of Zoo and Wildlife Medicine, 12(2), 111-115. doi: 10.5686/jjzwm.12.111.

Say, L., Devillard, S., Natoli, E., \& Pontier, D. (2002). The mating system of feral cats (Felis catus L.) in a sub-Antarctic environment. Polar Biology, 25, 838842. doi: 10.1007/s00300-002-0427-2.

Schwarzenberger, F., Möstl, E., Palme, R., \& Bamberg, E. (1996). Faecal steroid analysis for non-invasive monitoring of reproductive status in farm, wild and zoo animals. Animal Reproduction Science, 42(1-4), 515-526. doi: 10.1016/0378-4320(96)01561-8.

Schwarzenberger, J. C., \& Gogarten, W. (2007). Anesthesia for patients with congenital heart disease undergoing non-cardiac surgery. Anasthesiol Intensivmed Notfallmed Schmerzther, 42(11), 822-832. doi: 10.1055/s-2007-1003596.

Shille, V. M., Munro, C., Farmer, S. W., \& Papkoff, H. (1983). Ovarian and endocrine responses in the cat after coitus. J. Reprod. Fertil., 69(1), 29-39. doi: 10.1530/jrf.0.0690029.

Stewart, D. R., \& Stabenfeldt, G. H. (1985). Relaxin activity in the pregnant cat. Biol Reprod, 32(4), 848854. doi: 10.1095/biolreprod32.4.848.

Touma, C., \& Palme, R. (2005). Measuring fecal glucocorticoid metabolites in mammals and birds: the importance of validation. Annals of the New York 
Academy of Sciences, 1046(1), 54-74. Wildt, D. E., Brown, J. L., \& Swanson, W. F. (1998). doi: 10.1196/annals.1343.006.

Reproduction in cats. In: Knobil, E., Neill, J. (Eds.), Encyclopedia of Reproduction, 1st ed. Academic Press, New York, 497-510.

M., Silveira, L., Freitas T. R. O., \& Eizirik, E. (2013).

Molecular data reveal complex hybridization and a cryptic species of neotropical wild cat. Curr Biol., 23(24), 2528-2533. doi: 10.1016/j.cub.2013.10.046.

Umapathy, G., Kumar, V., Wasimuddin, Kabra, M., \& Shivaji, S. (2013). Detection of pregnancy and fertility status in big cats using an enzyme immunoassay based on 5 $\alpha$-pregnan-3 $\alpha$-ol-20-one. Gen Comp Endocrinol, Wilting, A., Buckley-Beason, V. A., Feldhaar, H., Gadau, J., O'Brien, S. J., \& Eduard Linsenmair K. (2007). Clouded leopard phylogeny revisited: support for species recognition and population division between Borneo and Sumatra. Front Zool., 4, 15. doi: 10.1186/1742-9994-4-15. 